\title{
Frammistaða Landspítala í forvörnum gegn bláæðasegasjúkdómum; pversniðsrannsókn á bráðadeildum
}

\author{
Hallgerður Lind Kristjánsdóttir ${ }^{1}$ lknir, Guơný Stella Guð̃nadóttir ${ }^{1}$ læknir, Sigríður Bára Fjalldal ${ }^{1}$ læknir, Hulda Rósa Pórarinsdóttir ${ }^{2}$ læknir, \\ Agnar Bjarnason ${ }^{1}$ læknir, Óskar Einarsson' læknir
}

\section{ÁGRIP}

Tilgangur: Bláæđasegasjúkdómar eru alvarlegir og geta verið banvænir fylgikvillar sjúkrahúsinnlagna. Erlendar rannsóknir sýna að forvarnarmeðferð gegn bláæðasegum er víða ábótavant. Markmið pessarar rannsóknar var að meta frammistöðu Landspítala í forvörnum gegn bláæðasegasjúkdómum hjá inniliggjandi sjúklingum á bráđadeildum fullorðinna. Efniviður og aðferð̌ir: Pann 2. desember 2009 var farið yfir sjúkraskrár allra inniliggjandi sjúklinga bráđadeilda Landspítala. Kannað var hvort viðkomandi fengi fyrirbyggjandi meðferð gegn bláæðasegasjúkdómum samkvæmt leiðbeiningum American College of Chest Physicians frá 2008. Niðurstöðurnar voru bornar saman við árangur annarra landa úr fjölpjóðarannsókninni Endorse frá 2008.
Niðurstöður: Inntökuskilyrði uppfyllti 251 sjúklingur. Inniliggjandi sjúklingar á Landspítala höfðu í 47\% tilfella ábendingu fyrir forvarnarmeðferð gegn bláæðasegasjúkdómum. Af pessum áhættusjúklingum fengu 57\% forvörn, eða i $78 \%$ tilfella á skurðlækningadeildum og i $26 \%$ tilfella á lyflækningadeildum.

Ályktanir: Árangur skurðlækningadeilda Landspítala var góður pegar niðurstöđur úr Endorse-rannsókninni voru hafðar til samanburðar. Árangur lyflækningadeilda var hins vegar verri við hliðstæðan samanburð. Niðurstöđur okkar gefa til kynna að bæta mætti frammistöðu Landspítala í forvörnum gegn bláæðasegasjúkdómum og auka par með sjúklingaöryggi.

\section{Inngangur}

Segamyndun í djúpum bláæðum (deep vein thrombosis) og blóðsegarek til lungna eru algengir sjúkdómar. Sameiginlega ganga pessir tveir sjúkdómar undir heitinu bláæðasegasjúkdómar og hér verður eftirleiðis rætt um pá sem eina heild. Í Evrópusambandslöndum eru áætluð yfir 1,5 milljón tilfelli árlega, út frá faraldsfræðilegu líkani par sem sjúklingar greinast með sjúkdóminn í fyrsta sinn, fá endurtekna bláæðasegamyndun eða látast af völdum pessara sjúkdóma. ${ }^{1}$ Í sömu löndum er áætlað að yfir 500.000 látist af völdum bláæðasegasjúkdóma á hverju ári. Samkvæmt pessu deyja fleiri árlega af völdum bláæðasegasjúkdóma en af völdum brjóstakrabbameins, blöðruhálskirtilskrabbameins, alnæmis og umferðarslysa samanlagt. ${ }^{1,2}$ Blóðsegarek til lungna veldur allt að 5-10\% dauðsfalla inniliggjandi sjúklinga.,34 Minnka má hættuna á myndun bláæðasega með fyrirbyggjandi meðferð og er blóðsegarek til lungna talið vera algengasta dánarorsökin innan spítala sem hægt er að fyrirbyggja. ${ }^{3,5-7}$ Klínískar leiðbeiningar um notkun fyrirbyggjandi meðferðar gegn bláæðasega hafa verið til staðar í meira en 15 ár. Prátt fyrir pað er notkun fyrirbyggjandi meðferðar hjá sjúklingum í áhættu víða ábótavant. ${ }^{8,9}$ Á árunum 2007-2008 fór fram alpjóðleg rannsókn (Endorse) par sem metið var hversu stór hluti inniliggjandi sjúklinga á bráđadeildum var í hættu á að fá bláæðasegasjúkdóm samkvæmt klínískum leiðbeiningum frá The American College of Chest Physicians (ACCP). ${ }^{710}$ Í ljós kom að rúmlega helmingur (51,8\%) inniliggjandi sjúklinga bráđadeilda hafa ábendingu fyrir fyrirbyggjandi meðferð gegn bláæðasegasjúkdómum. Af peim fengu eingöngu 58,5\% sjúklinga á skurðlækningadeildum og 39,5\% sjúklinga á lyflækningadeildum viðeigandi fyrirbyggjandi meðferð. ${ }^{10}$

Tilgangur rannsóknarinnar var að kanna hversu margir sjúklingar lyflækninga-, gjörgæslu- og skurðlækningadeilda Landspítala hafa ábendingu fyrir að fá fyrirbyggjandi meðferð gegn bláæðasegasjúkdómum. Jafnframt var kannað hversu stór hluti pessa áhættuhóps fékk viðeigandi meðferð samkvæmt klínískum leiðbeiningum ACCP.7 Niðurstöðurnar voru bornar saman við niðurstöður úr Endorse-rannsókninni. ${ }^{10}$

\section{Efniviður og aðferðir}

Rannsóknin er pversniðsrannsókn framkvæmd á einum degi á inniliggjandi sjúklingum á lyf- og skurðlækningadeildum og gjörgæsludeildum Landspítala. Tilgangurinn var að kanna frammistöðu bráðadeilda Landspítala í að veita fyrirbyggjandi meðferð gegn bláæðasegasjúkdómum. Listi yfir inniliggjandi sjúklinga á viðkomandi deildum var fenginn klukkan 8 að morgni pann 2. desember 2009 og sjúkraskrár peirra yfirfarnar. Upplýsingum var safnað um lýðfræðilegar breytur, innlagnarástæðu, fjölda legudaga, áhættupætti fyrir bláæðasegasjúkdómum og frábendingar fyrir fyrirbyggjandi meðferð gegn bláæðasega. Jafnframt var kannað hvort viðkomandi væri á fyrirbyggjandi meðferð og hvort sú meðferð væri viðeigandi samkvæmt ACCP-leiðbeiningum, líkt og gert var í Endorse-rannsókninni (sjá fylgiskjöl 1 og 2 á www.laeknabladid.is), Á skurðlækningadeildum voru peir sjúklingar sem fóru í stóra eða meðalstóra skurðaðgerð sem krafðist svæf- 


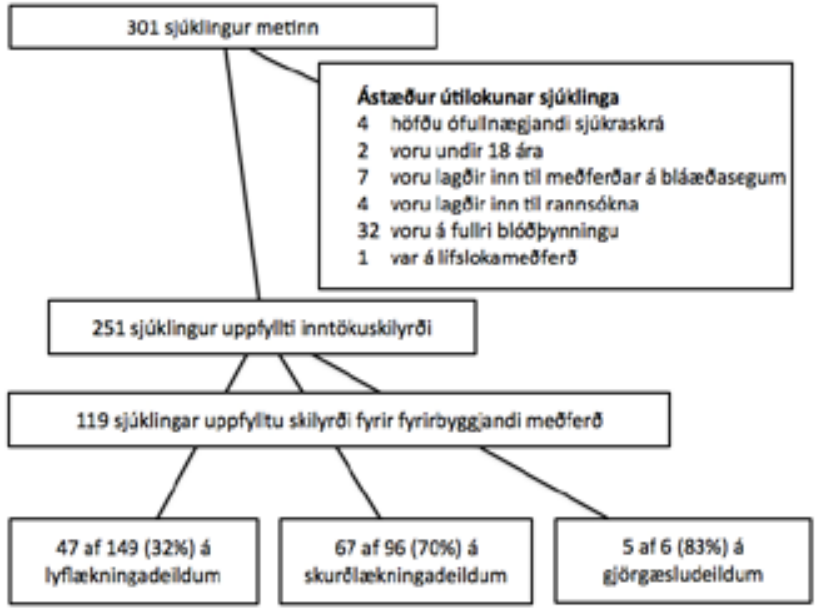

Mynd 1. Val á rannsóknarpýði og orsakir útilokunar.

ingar eða utanbastdeyfingar í meira en 45 mínútur metnir eiga á hættu á að fá bláæðasegasjúkdóma. Á lyflækningadeildum voru peir taldir í áhættuhóp sem lögðust inn vegna eða fengu í legu: 1) alvarlega hjartabilun (NYHA-flokkur III/IV) eða alvarlegan lungnasjúkdóm ( $\mathrm{SpO}_{2}<90 \%$ eða $\left.\left.\mathrm{pO}_{2}<60 \mathrm{mmHg}\right), 2\right)$ sjúklingar sem voru rúmliggjandi eða með skerta fótaferð, auk fyrri sögu um bláæðasegasjúkdóm, með virkt krabbamein eða í krabbameinsmeðferð, með brátt kransæðaheilkenni, með virkan gigtar- eða bólgusjúkdóm, með sýkingu eða heilaáfall og 3) sjúklingar sem lagst höfðu á gjörgæslu í legunni. Pá bárum við árangur Landspítala saman við árangur annarra landa úr Endorse-rannsókninni. Afstæðar frábendingar fyrir fyrirbyggjandi meðferð gegn bláæðasegasjúkdómum með blóðpynnandi lyfjum voru heilablæðing, blæðing sem parfnaðist krossprófunar, blæðandi magaeða skeifugarnarsár innan fjögurra vikna, sýking í hjartalokum, nýrnabilun með gaukulsíunarhraða minni en $30 \mathrm{ml} / \mathrm{mín} / 1,73 \mathrm{~m}^{2}$ og blóðflögur færri en 100 pús/ $\mu \mathrm{L}$.

\section{Sjúklingahópur}

Sjúklingar 18 ára eða eldri innlagðir á skurðlækninga-, lyflækninga- og gjörgæsludeild voru með í rannsókninni. Útilokaðir voru peir sem lögðust inn vegna bláæðasegasjúkdóms, voru á fullum skömmtum af léttheparíni (low molecular weight heparin) eða warfaríni, innlagðir til rannsókna, hlutu lífslokameðferð, fóru í aðgerð par sem svæfingartími var minni en 45 mínútur eða par sem skráning var ófullnægjandi. Sjúklingar á barnadeild, háls-, nef- og eyrnadeild, húðdeild, geðdeild, líknardeild, endurhæfingardeild, öldrunardeild (nema B4-bráðadeild öldrunar) og sjúklingar á kvennadeild sem tilheyrðu fæðingardeild voru ekki teknir með í rannsóknina.

\section{Tölfræði og leyfi}

Notast var við einfalda lýsandi tölfræði. Megindlegar breytur voru settar fram sem miðgildi, fjórðungsbil og fjöldi sjúklinga. Flokkunargögn voru sett fram sem fjöldi einstaklinga og hlutfall af hópnum. Gögnum var safnað fyrst á sérútbúin eyðublöð og upplýsingar pá færðar inn í File-Maker Pro 8.0v2 gagnagrunn. Við tölfræðiútreikninga var notast við tölfræðiforritið SPSS 19. Tilskilin leyfi voru veitt frá siðanefnd Landspítala (37-2009) og Persónuvernd (2009/654). Engum persónugreinanlegum upplýsingum var safnað í rannsókninni.

\section{Niðurstöður}

Pann 2. desember 2009 lágu 301 sjúklingur á ofangreindum deildum. Af peim uppfylltu 251 inntökuskilyrði og 119 uppfylltu skilyrði fyrir að fá forvarnarmeðferð gegn bláæðasegasjúkdómum. Skipting peirra á deildir má sjá á mynd 1. Aldur, pyngd og lengd spítaladvalar má sjá í töflu I og innlagnarástæður sjúklinga má sjá í töflu II. Sjúklingar sem höfðu ábendingu fyrir forvörn gegn bláæðasega voru eldri og höfðu dvalið lengur á spítala samanborið við aðra. Skráningu á hæð og pyngd var ábótavant svo einungis var hægt að reikna líkamspyngdarstuðul (Body Mass Index, BMI) hjá hluta sjúklinga. Á lyflækningadeildum voru $14 \%(n=21)$ sjúklinga með skráða bæði hæð og pyngd en 54\% (n=52) á skurðlækningadeildum og 50\% sjúklinga ( $n=3)$ á gjörgæsludeildum.

Á lyflækningadeildum voru 47 sjúklingar með ábendingu fyrir forvarnarmeðferð. Af peim fengu $26 \%$ sjúklinga fyrirbyggjandi meðferð. Algengasta ábending sjúklinga sem fengu viðeigandi forvörn var rúmlega og að minnsta kosti einn áhættupáttur, en algengasta ábending sjúklinga sem vantaði viðeigandi vörn var alvarlegur lungnasjúkdómur (tafla III). Á skurðlækningadeildum voru 67 sjúklingar með ábendingu fyrir fyrirbyggjandi meðferð. Af peim fengu $78 \%$ forvörn. Hjá peim sem vantaði viðeigandi forvörn var algengara að peir væru með aðra ábendingu en aðgerðina sjálfa (tafla III). Á gjörgæslu voru 5 sjúklingar með ábendingu fyrir fyrirbyggjandi meðferð og af peim fengu fjórir forvörn. Allir gjörgæslusjúklingar höfðu aðgerð sem ábendingu fyrir fyrirbyggjandi meðferð, tveir voru rúmliggjandi og með að minnsta kosti einn áhættupátt. Sá sjúklingur sem fékk ekki bláæðasegavörn var rúmliggjandi með einn áhættupátt. Hlutlægar frábendingar

Tafla I. Samanburður á lýðfræðilegum breytum sjúklinga, háð pví hvort peir eiga eða eiga ekki að vera á forvörn gegn bláæðasegasjúkdómum. Gögn eru sett fram sem fjöldi og prósentuhlutfall nema annað sé tekið fram.

\begin{tabular}{|c|c|c|c|c|c|c|}
\hline & \multicolumn{2}{|c|}{ Sjúklingar á lyflækningadeild } & \multicolumn{2}{|c|}{ Sjúklingar á skurðlækningadeild } & \multicolumn{2}{|c|}{ Sjúklingar á gjörgæsludeild } \\
\hline & $\begin{array}{c}\text { Eiga að vera á } \\
\text { blóðsegavörn }(n=47)\end{array}$ & $\begin{array}{c}\text { Eiga ekki að vera á } \\
\text { blóðsegavörn }(n=102)\end{array}$ & $\begin{array}{c}\text { Eiga að vera á } \\
\text { blóðsegavörn }(n=67)\end{array}$ & $\begin{array}{l}\text { Eiga ekki að vera á } \\
\text { blóðsegavörn }(n=29)\end{array}$ & $\begin{array}{c}\text { Eiga að vera á } \\
\text { blóðsegavörn }(n=5)\end{array}$ & $\begin{array}{l}\text { Eiga ekki að vera á } \\
\text { blóðsegavörn }(n=1)\end{array}$ \\
\hline Kyn (konur) & $21(62 \%)$ & $55(54 \%)$ & $37(55 \%)$ & $13(45 \%)$ & $2(40 \%)$ & $1(100 \%)$ \\
\hline Aldur (ár)* & $78(63-83)$ & $69(56-80)$ & $67(54-77)$ & $57(39-76)$ & $41(40-61)$ & 61 \\
\hline $\begin{array}{l}\text { Lengd spítala- } \\
\text { dvalar (dagar) }\end{array}$ & $8(2-14)$ & $5(2-9)$ & $6(2-9)$ & $2(1-4)$ & $2(1-10)$ & 1 \\
\hline BMI $\left(\mathrm{kg} / \mathrm{m}^{2}\right)^{\star \star}$ & $23(19-29)(n=3)$ & $27(24-31)(n=18)$ & $27(23-29)(n=39)$ & $26(24-27)(n=12)$ & $28(28-37)(n=3)$ & Ópekkt \\
\hline Pyngd $(\mathrm{kg})^{\star \star \star}$ & $71(63-80)(n=24)$ & $78(62-90)(n=41)$ & $73(65-87)(n=60)$ & $80(72-89)(n=17)$ & $89(75-115)(n=4)$ & $81(n=1)$ \\
\hline
\end{tabular}

*Miðgildi (interquartile range); **BMl=Líkamspyngdarstuðull, reiknast ekki ef ekki lágu fyrir upplýsingar um bæði hæð og pyngd; **^Pyngd var ekki mæld hjá öllum sjúklingum 
Tafla II. Innlagnarástæður sjúklinga á Landspítala sem uppfylla skilyrði fyrirbyggjandi meðferðar gegn bláæðasegum og peirra sem uppfylla ekki skilyrðin

\begin{tabular}{|c|c|c|}
\hline $\begin{array}{l}\text { Innlagnarástæður á } \\
\text { lyflækningadeild }\end{array}$ & $\begin{array}{c}\text { Eiga að̃ vera á } \\
\text { blóðsegavörn } \\
\text { n=47 (\%) }\end{array}$ & $\begin{array}{c}\text { Eiga ekki að vera á } \\
\text { blóðsegavörn } \\
n=102(\%)\end{array}$ \\
\hline $\begin{array}{l}\text { Bráđur lungnasjúkdómur } \\
\text { (ekki sýking) }\end{array}$ & $7(15)$ & $3(3)$ \\
\hline Brád hjartabilun & $1(2)$ & $0(0)$ \\
\hline $\begin{array}{l}\text { Annar hjarta- og } \\
\text { æðasjúkdómur }\end{array}$ & $3(6)$ & $6(6)$ \\
\hline Blóðsjúkdómur & $1(2)$ & $11(11)$ \\
\hline Virkt krabbamein & $9(19)$ & $7(7)$ \\
\hline Lungnasýking & $10(21)$ & $8(6)$ \\
\hline $\begin{array}{l}\text { Meltingar- eða lifrarsjúkdómur, } \\
\text { ekki bólgusjúkdóma }\end{array}$ & $3(6)$ & $13(13)$ \\
\hline Nýrnasjúkdómur & $6(13)$ & $4(4)$ \\
\hline $\begin{array}{l}\text { Sýking annars staðar en í } \\
\text { öndunarfærum }\end{array}$ & $6(13)$ & $15(15)$ \\
\hline Taugasjúkdómur & $4(9)$ & $18(18)$ \\
\hline Annad ${ }^{* \star}$ & $15(32)$ & $35(34)$ \\
\hline $\begin{array}{l}\text { Innlagnarástæður á } \\
\text { skurðlækningadeild }\end{array}$ & $\begin{array}{c}\text { Eiga að vera á } \\
\text { blóðsegavörn } \\
n=67(\%)\end{array}$ & $\begin{array}{c}\text { Eiga ekki að vera á } \\
\text { blóðsegavörn } \\
n=29(\%)\end{array}$ \\
\hline Aðgerð á meltingarfærum & $8(12)$ & $3(11)$ \\
\hline Heila- og taugaaðgerð & $1(2)$ & $4(14)$ \\
\hline Brjóstholsaðgerð & $7(10)$ & $0(0)$ \\
\hline Pvagfæraaðgerð & $3(5)$ & $6(21)$ \\
\hline Virkt krabbamein & $5(8)$ & $2(7)$ \\
\hline Kvenlíffæraaðgerð & $10(15)$ & $0(0)$ \\
\hline Mjaðmabrot & $8(12)$ & $0(0)$ \\
\hline Mjaðmaliðskipti & $6(9)$ & $0(0)$ \\
\hline Ađrir bæklunaráverkar & $4(6)$ & $9(32)$ \\
\hline $\begin{array}{l}\text { Innlögn vegna áverka, aðgerð } \\
\text { ekki gerð }\end{array}$ & $0(0)$ & $2(7)$ \\
\hline Annað*** & $21(31)$ & $4(14)$ \\
\hline
\end{tabular}

* Sjúklingar geta haft fleiri en eina innlagnarástæðu.

**Innlagnarástæða fellur undir annað ef að hún var til staðar hjá undir $5 \%$. Hjartabilun er pó sýnd par sem hún er alltaf ástæða fyrirbyggjandi meðferðar.
Tafla III. Ábendingar fyrir fyrirbyggjandi meðferð gegn bláæðasegum hjá sjúklingum sem fengu viðeigandi forvörn og hjá sjúklingum sem vantaði forvörn.

\begin{tabular}{|c|c|c|}
\hline Lyflækningadeild & $\begin{array}{c}\text { Með viðeigandi } \\
\text { blóðsegavörn } n=12 \text { (\%) }\end{array}$ & $\begin{array}{l}\text { Vantar blóðsegavörn } \\
\qquad n=35(\%)\end{array}$ \\
\hline Bráð hjartabilun & $3^{\star \star}(25)$ & $8^{\star \star}(23)$ \\
\hline $\begin{array}{l}\text { Alvarlegur } \\
\text { lungnasjúkdómur }\end{array}$ & $3(25)$ & $14(40)$ \\
\hline $\begin{array}{l}\text { Rúmlega og að minnsta } \\
\text { kosti einn áhættupáttur* }\end{array}$ & $8(67)$ & $13(37)$ \\
\hline Skurðlækningadeild & $\begin{array}{c}\text { Með viðeigandi } \\
\text { blóðsegavörn } n=52 \text { (\%) }\end{array}$ & $\begin{array}{l}\text { Vantar blóðsegavörn } \\
\qquad n=15(\%)\end{array}$ \\
\hline Aðgerð & $47^{\star \star}(90)$ & $12^{\star \star}(80)$ \\
\hline Bráđ hjartabilun & $3(6)$ & $0(0)$ \\
\hline $\begin{array}{l}\text { Alvarlegur } \\
\text { lungnasjúkdómur }\end{array}$ & $1(2)$ & $0(0)$ \\
\hline $\begin{array}{l}\text { Rúmlega og að minnsta } \\
\text { kosti einn áhættupáttur }\end{array}$ & $19(37)$ & $5(33)$ \\
\hline
\end{tabular}

*Áhættupættir sem eru ábending fyrir blóđsegavörn pegar peir fara saman með rúmlegu eru: fyrri saga um bláæđasegasjúkdóma, heilablóðfall, virkt krabbamein, virk krabbameinslyfjameđferð, gigtarsjúkdómur eđa annar virkur bólgusjúkdómur, brátt kransæðaheilkenni, innlögn á gjörgæslu í sjúkrahúslegu.

**Súklingar geta haft fleiri en eina ábendingu, til dæmis bæði hjartabilun og alvarlegan ** Sjúklingar geta
lungnasjúkdóm.

gegn notkun blóðpynnandi lyfja voru til staðar hjá 28\% (n=13) af sjúklingum á lyflækningadeildum sem uppfylltu skilyrði fyrir blóðsegavörn. Sex sjúklingar höfðu nýrnabilun með gaukulsíunarhraða undir $30 \mathrm{ml} / \mathrm{mín} / \mathrm{m}^{2}$, fjórir blæðingu sem krafist hafði blóðgjafar, einn hafði heilablæðingu og blæðingu sem krafðist blóðgjafar og loks höfðu tveir truflun í storkukerfi með lækkun blóðflagna. Fjórir sjúklinganna með afstæða frábendingu fengu meðferð með blóðpynnandi lyfjum. Enginn hinna 9 sjúklinga sem voru án blóðpynnandi lyfja fékk stoðsokka. Hlutlægar frábendingar voru til staðar hjá 10\% (n=5) sjúklinga skurðlækningadeilda. Einn sjúklingur hafði heilablæðingu, einn pekkta truflun í storkukerfi, tveir höfðu nýrnabilun með gaukulsíunarhraða undir 30ml/ mín/ $\mathrm{m}^{2}$ og einn hafði blæðingu sem krafðist blóðgjafar. Prír af 5 sjúklingum á gjörgæsludeildum sem uppfylltu skilyrðin fyrir fyrirbyggjandi meðferð höfðu hlutlægar frábendingar fyrir slíkri meðferð en fengu engu að síður forvörn. Sá sjúklingur sem ekki fékk fyrirbyggjandi meðferð hafði enga frábendingu.

Árangur Landspítala samanborið við önnur lönd sem tóku pátt í Endorse-rannsókninni er sýndur á mynd 2. Í heild reyndust $47 \%$
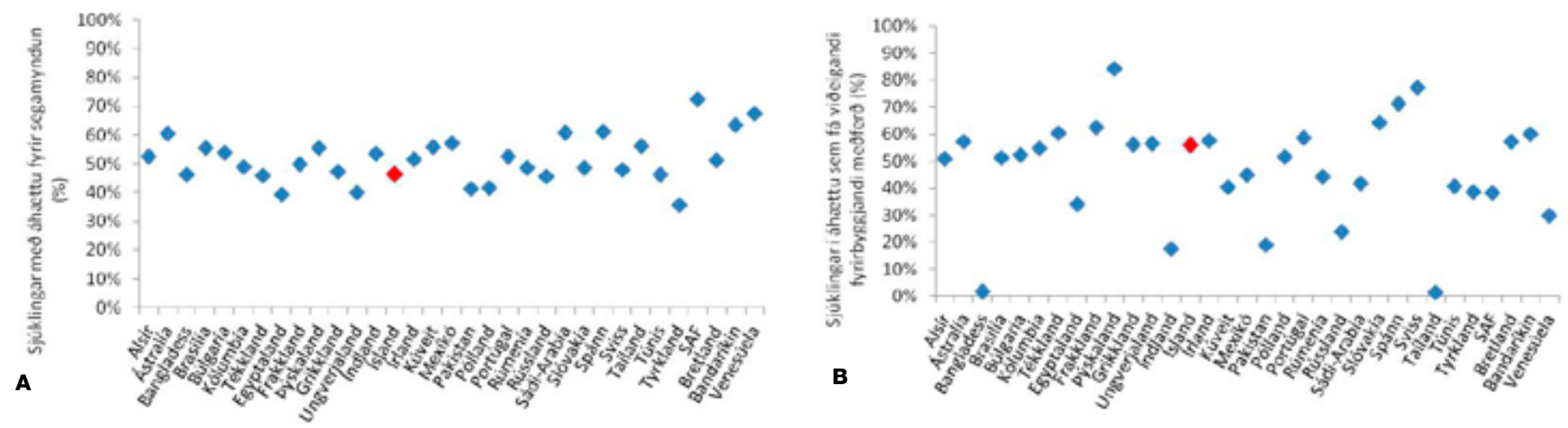

Mynd 2. A) Hlutfall sjúklinga í áhættu á að fá bláxðasegasjúkdóma á Landspitala samanborið við niðurstöður Endorse-rannsóknarinnar fyrir önnur lönd. ${ }^{10}$ B) Hlutfall sjúklinga í áhættu á að fá bláæðasegasjúkdóma sem fá forvörn á Landspítala samanborið við niðurstöður Endorse-rannsóknarinnar fyrir önnur lönd. ${ }^{10}$ 

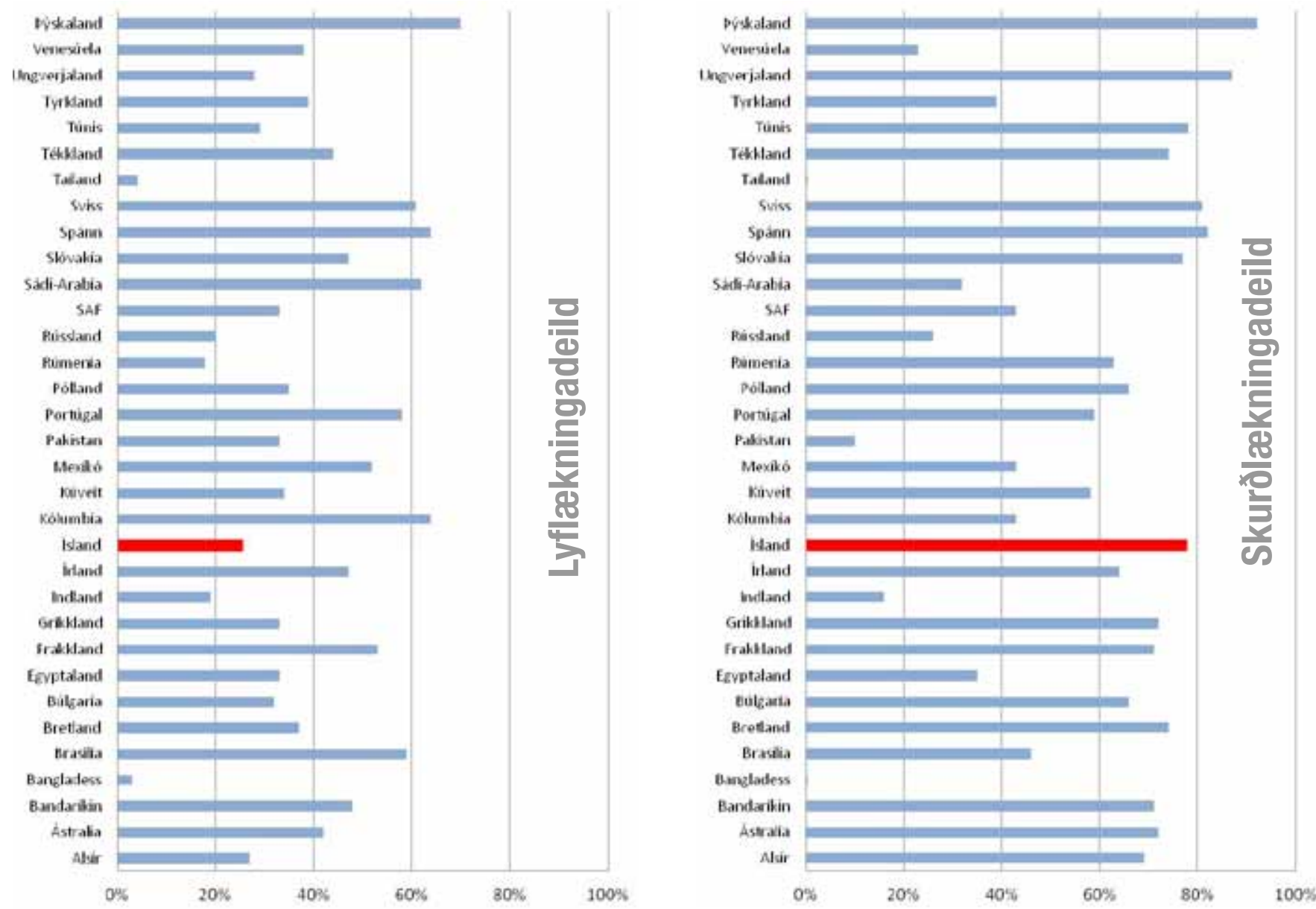

Mynd 3. A) Hlutfall sjúklinga á lyflækningadeildum í áhættu sem fá forvörn í samræmi við ACCP-leiðbeiningarnar. ${ }^{7}$

B) Hlutfall sjúklinga á skurðlækningadeildum í áhættu sem fá forvörn í samræmi við ACCP-leiðbeiningarnar.?

sjúklinga á Landspítala tilheyra áhættuhópi fyrir að fá bláæðasegasjúkdóm en í öðrum löndum var miðgildi 51\% (fjórðungsbil 46-56\%). Sá hluti áhættuhópsins sem fékk viðeigandi meðferð var $56 \%$ á Landspítala en í öðrum löndum var miðgildi 51\% (fjórðungsbil 38-58\%). Alls voru 13 af 33 löndum með betri árangur en Landspítali en ef lyf- og skurðlækningadeildir eru skoðaðar sér voru 28 lönd með betri árangur en á lyflækningadeildum en einungis fjögur með betri árangur en á skurðlækningadeildum. Nánar má sjá pessa skiptingu á mynd 3 og töflu IV í fylgiskjali 3 á heimasíðu Læknablaðsins. Íslenska úrtakið var minna en í nokkru landanna sem tóku pátt í Endorse-rannsókninni. Allir sjúklingar sem fengu fyrirbyggjandi meðferð gegn bláæðasega á Landspítala fengu léttheparín að frátöldum einum sjúklingi á skurðlækningadeild sem fékk óklofið heparín. Önnur blóðpynnandi lyf voru ekki notuð sem fyrirbyggjandi meðferð á Landspítala. Prír sjúklingar á lyflækningadeild voru með fyrirmæli um fótaferð en enginn á skurðlækningadeild. Einn sjúklingur á gjörgæsludeild var í stoðsokkum en engir á lyf- eða skurðlækningadeildum.

\section{Umræður}

Niðurstöður okkar benda til pess að á Landspítala fái aðeins helmingur peirra sjúklinga sem tilheyra áhættuhópi fyrir bláæðasegasjúkdómum viðeigandi fyrirbyggjandi meðferð. Frammistaða á skurðlækningadeildum var hins vegar mjög góð, par sem $78 \%$ áhættusjúklinga fékk viðeigandi forvörn, meðan á lyflækningadeildum fengu einungis $26 \%$ áhættusjúklinga slíka forvörn. Séu pessar niðurstöður bornar saman við Endorse-löndin er árangur á skurðlækningadeildum mjög góður og eru pær í 5. sæti í röð 33 landa en árangri lyflækningadeilda er ábótavant og eru pær í 28. sæti af 33 löndum. ${ }^{10}$

Talið er að um 10-20\% af bráðveikum sjúklingum á lyflækningadeildum og 40-60\% af sjúklingum á skurðlækningadeildum prói með sér bláæðasega, fái peir ekki fyrirbyggjandi meðferð. ${ }^{7}$ Rannsóknir hafa bent til að notkun fyrirbyggjandi meðferðar minnki hættuna á bláæðasega um allt að helming hjá bráðveikum sjúklingum á lyflækningadeildum og um allt að tvo priðju hjá sjúklingum á skurðlækningadeildum. ${ }^{11-13}$ Í hópi skurðsjúklinga er talið að fyrirbyggjandi meðferð lækki dánartíðni bæði vegna lungnasegareks og vegna dauða af öðrum orsökum, til dæmis bráðs kransæðaheilkennis., ${ }^{5,4}$ Áhrif fyrirbyggjandi meðferðar á dánartíðni í hópi bráðveikra sjúklinga á lyflækningadeildum er hins vegar ekki eins skýr. Sumar rannsóknir hafa bent til að fyrirbyggjandi meðferð minnki dánartíðni en aðrar hafa ekki sýnt mun milli hópanna. ${ }^{13,15}$ Ekki er ljóst af hverju pessi munur sést milli lyfog skurðlækningadeilda en ein skýring er að bráðveikir sjúklingar á lyflækningadeilum hafi fleiri undirliggjandi sjúkdóma og áhrif fyrirbyggjandi meðferðar vegi pví minna. Pó skal ekki gleyma að 
fyrirbyggjandi meðferð minnkar tíðni djúpbláæðasega í ganglimum og sýnt hefur verið að 30-70\% peirra sem fá djúpbláæðasega í ganglim próa með sér eftirsegakvilla í ganglim innan 10 ára. ${ }^{16,17}$

Aðrar rannsóknir hafa einnig sýnt að áhættusjúklingum á skurðlækningadeildum er oftar veitt viðeigandi fyrirbyggjandi meðferð en peim á lyflækningadeildum og er árangur oftast bestur á bæklunar- og almennum skurðlækningadeildum..$^{10}$ Mögulegar skýringar gætu verið að skurðlæknar eru almennt betur meðvitaðir um áhættuna á bláæðasega auk pess sem par eru einfaldar skilgreiningar á hverjir eru í áhættu. Pví miður virðist raunin sú að sjúklingar með alvarlega hjartabilun, alvarlegan lungnasjúkdóm og veikir krabbameinssjúklingar fái oft ekki viðeigandi forvarnar- meðferð prátt fyrir að hafa vel pekkta áhættupætti. Pá má nefna að enginn áhættusjúklingur $(\mathrm{n}=6)$ á krabbameinsdeild í pessari rannsókn fékk viðeigandi forvarnarmeðferð. Einnig vantaði fyrirbyggjandi meðferð hjá meirihluta peirra sem voru í áhættu vegna hjartabilunar eða alvarlegs lungnasjúkdóms (tafla III). Önnur möguleg skýring á lítilli notkun fyrirbyggjandi meðferðar gegn bláæðasega er ótti við blæðingar. Hættan á slíku við notkun léttheparíns í fyrirbyggjandi skömmtum er hins vegar talin hverfandi. ${ }^{18}$ Að auki eiga peir sjúklingar sem hafa frábendingu samt sem áður að fá fyrirbyggjandi meðferð með stoðsokkum eða hreyfipumpumeðferð (intermittent pneumatic compression), sem er lítið notuð hér á landi.

Rannsóknin hefur sínar takmarkanir. Meðferð sjúklinga var aðeins könnuð á einum degi. Rannsóknin var hins vegar framkvæmd undir „venjulegum” starfsskilyrðum utan sumarleyfistíma. Ekki er pví augljós ástæða fyrir pví að pessar niðurstöður endurspegli ekki daglega starfsemi. Gögnum rannsóknarinnar var eingöngu safnað úr sjúkraskrám en ekki með viðtölum, til dæmis við ábyrgan sérfræðing. Pví er mögulegt að við höfum ekki fengið allar nýjustu upplýsingar um sjúklingana og pá hvort ábending/ frábending var fyrir að veita forvörn við bláæðasegasjúkdómum. Skal pó nefna að peir sjúklingar voru útilokaðir $(\mathrm{n}=4)$ par sem sjúkraskrá vantaði eða okkur pótti skráning ófullnægjandi. Petta nægir pó ekki til að skýra pann stóra mun sem virðist vera milli leiðbeininga og raunveruleikans. Að lokum er ekki hægt að útiloka að starfsfólk hafi heyrt af gerð rannsóknarinnar og pví hagað vinnu sinni öðruvísi en vanalega. Með pversniðsformi hennar var pó reynt að koma í veg fyrir pann pátt. Til að geta borið frammistöðu á Landspítala á einfaldan hátt saman við árangur annarra landa ákváðum við að hanna rannsóknina með sama hætti og gert var í Endorse-rannsókninni. •að er pó augljós galli á íslenska pýðinu hversu lítið pað er, en pað er minna en önnur í Endorserannsókninni (sjá töflu IV í fylgiskjali 3). Til að geta verið með í Endorse-rannsókninni var pó einungis miðað við sjúkrahús með 50 rúmum og uppfylltum við ríflega pau skilmerki. Sjúklingahópurinn, pað er að segja hversu margir eru í áhættu, er pó sambærilegur á Landspítala (47\%) miðað við aðra í Endorse-rannsókninni (miðgildi 51\%).

Slakur árangur í að veita fyrirbyggjandi meðferð gegn bláæðasegasjúkdómum og hið breiða bil milli gagnreyndrar læknisfræði og raunverulegrar notkunar á fyrirbyggjandi meðferð hefur orðið til pess að víða í Bandaríkjunum er fyrirbyggjandi meðferð gegn bláæðasegasjúkdómum orðið að stærsta öryggismáli sjúkrahúsa. ${ }^{19}$ Margpátta átak parf að eiga sér stað til að bæta árangur á Landspítala. Рað hefur reynst árangursríkt að nota fyrirframgerð matsblöð á áhættu á að fá bláæðasega sem fylla parf í við innlögn og eins parf að tryggja að klínískum leiðbeiningum sé framfylgt. ${ }^{20}$ Með fjölpátta inngripum hafa stofnanir bætt árangur sinn svo um munar og í rannsókn Bullock-Palmer og félaga fór notkun forvarna gegn bláæðasega úr 63\% í 96\% og tíðni sjúkrahústengdra djúpbláæðasega fór úr 2,6 í 0,2 á hverjar 1000 útskriftir. ${ }^{21}$

Með notkun fyrirbyggjandi meðferðar má koma í veg fyrir stóran hluta bláæðasegasjúkdóma og pannig minnka fylgikvilla og dánartíðni. Klínískar leiðbeiningar hafa verið til um árabil um hverjir eiga að fá slíka fyrirbyggjandi meðferð en prátt fyrir pað sýna faraldsfræðilegar rannsóknir fram á að peim er illa fylgt. Samkvæmt okkar rannsókn er frammistaða í að veita fyrirbyggjandi meðferð gegn bláæðasegasjúkdómum á Landspítala góð á skurðlækningadeildum en ábótavant á lyflækningadeildum. Leggjum við til að Landspítali fari að fordæmi stærri sjúkrahúsa erlendis og geri átak í að efla notkun á fyrirbyggjandi meðferð gegn bláæðasegasjúkdómum og bæta pannig sjúklingaöryggi.

\section{Pakkir}

Sérstakar pakkir fá læknanemarnir Agnes Björg Gunnarsdóttir, Anna Kristín Höskuldsdóttir, Ásgeir P. Porvaldsson, Gunnar Jóhannsson, Hrólfur Vilhjálmsson og Kristján Jónsson fyrir aðstoð við framkvæmd rannsóknarinnar. 


\section{Heimildir}

1. Cohen AT, Agnelli G, Anderson FA, Arcelus JI, Bergqvist $\mathrm{D}$, Brecht JG, et al. Venous thromboembolism (VTE) in Europe. The number of VTE events and associated morbidity and mortality. Thromb Haemost 2007; 98: 756-64.

2. Eurostat statistics on health and safety. epp.eurostat.eu/ portal/page/portal/eurostat/home. desember 2009.

3. Alikhan R, Peters F, Wilmott R, Cohen AT. Fatal pulmonary embolism in hospitalised patients: a necropsy review. J Clin Pathol 2004; 57:1 254-7.

4. Sandler DA, Martin JF. Autopsy proven pulmonary embolism in hospital patients: are we detecting enough deep vein thrombosis? J R Soc Med 1989; 82: 203-5.

5. Prevention of fatal postoperative pulmonary embolism by low doses of heparin. An international multicentre trial. Lancet 1975; 2: 45-51.

6. Anderson FA Jr, Wheeler HB, Goldberg RJ, Hosmer DW, Patwardhan NA, Jovanovic B, et al. A population-based perspective of the hospital incidence and case-fatality rates of deep vein thrombosis and pulmonary embolism The Worcester DVT Study. Arch Intern Med 1991; 151: 933 8.

7. Geerts WH, Bergqvist D, Pineo GF, Heit JA, Samama CM, Lassen MR, et al. Prevention of venous thromboembolism: American College of Chest Physicians Evidence-Based Clinical Practice Guidelines (8th Edition). Chest 2008; 133 . 381S-453S.

8. Amin A, Stemkowski S, Lin J, Yang G. Thromboprophylaxis rates in US medical centers: success or failure? J Thromb Haemost 2007; 5: 1610-6.
9. Piazza G, Seddighzadeh A, Goldhaber SZ. Double trouble for 2,609 hospitalized medical patients who developed deep vein thrombosis: prophylaxis omitted more often and pulmonary embolism more frequent. Chest 2007; 132: 554-61.

10. Cohen AT, Tapson VF, Bergmann JF, Goldhaber SZ, Kakkar AK, Deslandes B, et al. Venous thromboembolism risk and prophylaxis in the acute hospital care setting (ENDORSE study): a multinational cross-sectional study. Lancet 2008; 371: 387-94

11. Gangireddy C, Rectenwald JR, Upchurch GR, Wakefield TW, Khuri S, Henderson WG, et al. Risk factors and clinical impact of postoperative symptomatic venous thromboembolism. J Vasc Surg 2007; 45: 335-41; discussion 41-2.

12. Leizorovicz A, Cohen AT, Turpie AGG, Olsson C-G, Vaitkus PT, Goldhaber SZ, et al. Randomized, PlaceboControlled Trial of Dalteparin for the Prevention of Venous Thromboembolism in Acutely Ill Medical Patients. Circulation 2004; 110: 874-9.

13. Samama MM, Cohen AT, Darmon JY, Desjardins L, Eldor A, Janbon C, et al. A comparison of enoxaparin with placebo for the prevention of venous thromboembolism in acutely ill medical patients. Prophylaxis in Medical Patients with Enoxaparin Study Group. N Engl J Med 1999; 341: 793-800.

14. Collins R, Scrimgeour A, Yusuf S, Peto R. Reduction in Fatal Pulmonary Embolism and Venous Thrombosis by Perioperative Administration of Subcutaneous Heparin N Engl J Med 1988; 318: 1162-73.
15. Kakkar AK, Cimminiello C, Goldhaber SZ, Parakh R, Wang C, Bergmann J-F. Low-Molecular-Weight Heparin and Mortality in Acutely Ill Medical Patients. N Engl J Med 2011; 365: 2463-72.

16. Prandoni P, Lensing AW, Cogo A, Cuppini S, Villalta S, Carta $\mathrm{M}$, et al. The long-term clinical course of acute deep venous thrombosis. Ann Intern Med 1996; 125:1 -7.

17. Karlsson G, Riba P, Thoroddsson I, Gudbjornsson B. Segamyndun í djúpum bláæðum ganglima. Uppgiör frá FSA 1975-1990. Læknablaðið 2000; 86: 19-24.

18. Själander A, Jansson JH, Bergqvist D, Eriksson H, Carlberg B, Svensson P. Efficacy and safety of anticoagulant prophylaxis to prevent venous thromboembolism in acutely ill medical inpatients: a meta-analysis. J Int Med 2008; 263: 52-60.

19. Maynard G, Stein J. Designing and implementing effective venous thromboembolism prevention protocols: lessons from collaborative efforts. J Thromb Thrombolys 2010; 29: $159-66$.

20. Preventing Hospital-Acquired Venous Thromboembolism A Guide for Effective Quality Improvement. Society of Hospital medicine. hospitalmedicine.org/AM/ Template.cfm?Section=Quality_Improvement_Resource Rooms\&Template $=/ C M /$ ContentDisplay.cfm\&ContentID=6092. - ágúst 2010.

21. Bullock-Palmer RP, Weiss S, Hyman C. Innovative approaches to increase deep vein thrombosis prophylaxis rate resulting in a decrease in hospital-acquired deep vein thrombosis at a tertiary-care teaching hospital. J Hosp Med 2008; 3: 148-55.

\section{ENGLISH SUMMARY}

\section{Evaluation of thromboprophylactic therapy at Landspítali - The National University Hospital of Iceland; a cross-sectional study on acute wards}

Kristjánsdottir $\mathrm{HL}^{1}$, Gudnadottir GS${ }^{1}$, Fjalldal $\mathrm{SB}^{1}$, Thorarinsdottir $\mathrm{HR}^{2}$, Bjarnason $\mathrm{A}^{1}$, Einarsson $\mathrm{O}^{1}$

Objective: Venous thromboembolic disease is a serious and often fatal complication following hospital admission. Studies show that thromboprophylactic therapy for this condition is often underutilized. The aim of this study was to evaluate the performance of thromboprophylactic therapy at Landspítali - The University Hospital of Iceland in adult patients admitted to acute wards.

Methods and materials: On 2 December 2009 hospital charts of admitted patients on acute wards were reviewed and assessed for appropriatethromboprophylactic treatment according to the 2008 guidelines from The American College of Chest Physicians. The results were compared to those of other countries from the multinational Endorse study from 2008.
Results: 251 patient were included of whom $47 \%$ were considered at risk for venous thromboembolic disease. Of those $57 \%$ received appropriate thromboprophylactic treatment or $78 \%$ of surgical and $26 \%$ of medical patients.

Conclusions: Adherence to clinical guidelines for thromboprophylactic treatment at surgical wards of Landspítali - The National University Hospital of Iceland was good and well above the average compared to the results of the Endorse study. Performance on the medical wards was on the other hand below average. Our results show that application of thromoboprophylactic treatment at Landspítali could be improved and thereby enhance patient safety.

Key words: prophylactic treatment, venous thromboembolism, hospitalized patients.

Correspondence: Hallgerður Lind Kristjánsdóttir hallgerdur.lind@gmail.com

Departments of ${ }^{1}$ Medicine and ${ }^{2}$ Anasthesia and Intensive Care, Landspitali-University Hospital. 